\title{
Description of Sharon gen. nov. for the Chilean species Asaphes amoenus Philippi, 1861 (Coleoptera: Elateridae)
}

\author{
Elizabeth T. ARIAS-BOHART ${ }^{1, *} \&$ Mario ELGUETA ${ }^{2}$ \\ ${ }^{1}$ Essig Museum of Entomology, University of California, 1101 Valley Life Sciences Building, \\ Berkeley 94720, California, U.S.A. \\ ${ }^{2}$ Museo Nacional de Historia Natural, Área de Entomología, Casilla 787 Santiago \\ (Correo central), Chile. E-mail: mario.elgueta@mnhn.cl \\ *Corresponding author: etarias.bohart@berkeley.edu \\ ${ }^{1}$ urn:Isid:zoobank.org:author:C4C6AA8B-2959-429F-B076-997E88A556B7 \\ ${ }^{2}$ urn:1sid:zoobank.org:author:38E90DEF-73B1-46E0-A343-2F5C5D5405C8
}

\begin{abstract}
Sharon gen. nov. is here described to include Asaphes? amoenus Philippi, 1861 comb. nov. from Chile. A redescription of the species is based on the female holotype and material from different geographic locations. Candèze (1891) placed Asaphes amoenus and Parasaphes elegans in the suprageneric group Asaphites. We discuss differences between Sharon gen. nov. and Hemicrepidius Germar, 1839, where Asaphes amoenus was later placed by Blackwelder (1944). Based on morphological characters, Sharon gen. nov. appears to be related to Parasaphes Candèze, 1881, Wynarka Calder, 1986, and Tasmanelater Calder, 1996, all from Australia, suggesting Gondwanan relationships.
\end{abstract}

Keywords. Coleoptera, Asaphes, Sharon gen. nov., Chile, new genus.

Arias-Bohart E.T. \& Elgueta M. 2015. Description of Sharon gen. nov. for the Chilean species Asaphes amoenus Philippi, 1861 (Coleoptera: Elateridae). European Journal of Taxonomy 142: 1-15. http://dx.doi.org/10.5852/ ejt.2015.142

\section{Introduction}

Kirby (1837) erected Asaphes as a subgenus of Pedetes Kirby, 1837. Philippi (1861) described Asaphes? amoenus from Chile, based on one specimen only and stated that he was unsure of its generic placement. Apparently unaware of Philippi's earlier description, Candèze (1878) described the same species as Asaphes elegans. Candèze (1881) described Parasaphes elegans, from Queensland, Australia and placed it in "Asaphites" (based on its type genus Asaphes Kirby, 1837, nec Asaphes Walker, 1834 in Hymenoptera and therefore an unavailable name). Candèze (1891) included Asaphes Kirby, Parasaphes Candèze, Compsoctenus Philippi and Tibionema Solier in the "XIX tribu Asaphites", and placed amoenus within Asaphes. Calvert (1897) agreed with this combination. Fleutiaux (1907), however, placed amoenus within Parasaphes. Later, Blackwelder (1944) placed amoenus in the genus Hemicrepidius Germar, 1839. Bouchard et al. (2011) note that Asaphites Candèze, 1863: 207 belongs under the subfamily Oxynopterinae Candèze, 1857. 
Here, we transfer amoenus from Hemicrepidius to Sharon gen. nov., which we place within the subfamily Oxynopterinae.

\section{Materials and Methods}

Specimens and primary types repositories are from institutional and private collections. Acronyms follow those provided by the institution or Arnett et al. (1993).

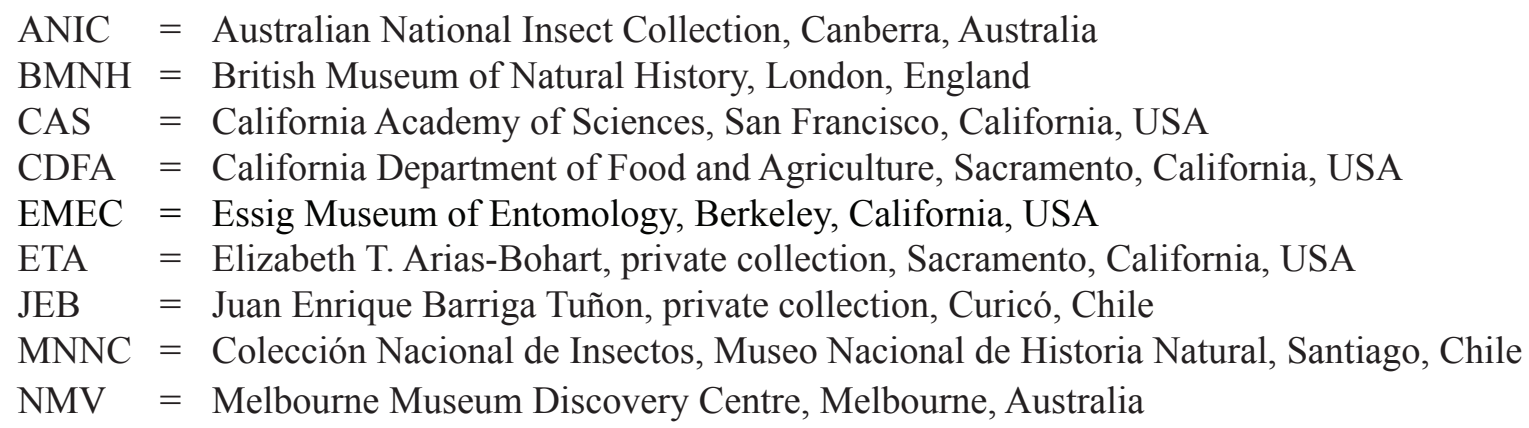

Measurements were made with a calibrated ocular micrometer as follows: total body length from the frontal margin to elytral apex; elytral width and maximum width of the elytra, when both sides are in focus.

The following procedure, as detailed by Becker (1958), was used for examining male and female genitalia: the last few abdominal segments were removed and placed overnight in a Petri dish with soapy water in order to soften the tissues. Male genitalia were extracted, examined and stored in small genitalia vials with $90 \%$ alcohol, or glued to a card, pinned under the specimen. Measurements using a calibrated ocular micrometer are as follows: total body length from the frontal margin to elytral apex; pronotal length and maximum width of the pronotum and elytral length and maximum width of elytra.

Methodology and adult morphology follow Platia (1994), Calder (1996), Lawrence \& Arias (2009), Lawrence et al. (2010a,b) and Arias-Bohart $(2013,2014)$. Wing vein nomenclature follows that of Dolin (1975) and Kukalová-Peck \& Lawrence (1993, 2004).

Label information includes original spellings of place names from specimen labels. Label data follows the following format: / = line separation within label, / / = label separation. Juan Enrique Barriga's collection labels include the URL http://www.coleoptera-neotropical.org, which is not included here. Approximate GPS values are given in parentheses. Drawings were made using a camera lucida on a Leica MZ7 dissecting microscope. Type material has been databased with a unique number indicated on the label consisting of the acronym EMEC followed by the identification number, which can be accessed at http://essigdb.berkeley.edu.

\section{Results}

Order Coleoptera Linnaeus, 1758

Family Elateridae Leach, 1815

Subfamily Oxynopterinae Candèze, 1857

Sharon gen. nov. urn:1sid:zoobank.org:act:A9250D0D-9E9D-4A12-B1E7-3C55FE9D8592

Type species: Asaphes? amoenus Philippi 1861: 743, here designated. 
ARIAS-BOHART E.T. \& ELGUETA M., Sharon amoenus (Philippi, 1861) gen. nov.

\section{Diagnosis}

This genus differs from all other elaterid genera by the following combination of characters: strongly serrate antennae from antennomere 4; frontoclypeal carena over antenna distinctive, diffuse at middle; frontoclypeal region advanced forward, concealing labrum at base; pronotum longer than wide, sides carinate and visible from above in almost all its enterity; in males pronotal sides straight, except at posterior angles; broad, protruding posterior angles, apices upwards; mesocoxa open to mesepimeron and mesepisternum; apical field of wing with one oblique, long narrow plate, reaching border of the wing. Sexual dimorphism present. Morphological characters of Sharon gen. nov. (Figs 1A-B, 2) are further discussed with Hemicrepidius (Fig. 3), where the species amoenus was last placed by Blackwelder (1944).

\section{Etymology}

This generic name honors Sharon P. Lawler of Davis, California, a long time friend.

\section{Description}

Female

Body about 4.27-4.97 times as long as wide; pronotal sides narrower than elytral sides; elytral maximum width at anterior third; elytral apices softly rounded, not meeting at mid-line (Fig. 1A-B. Holotype of type species MNNC).

Head slightly declined at base, transverse, ratio of median length to greatest postocular width $0.14-0.22$; eyes medium size, protuberant in both sexes, facetted, without interfacetal hairs; supra-antennal ridges raised above, each antennal fossa with deep curved invagination between antennal insertion and eye; antennomeres 2 and 3 significantly smaller that remaining antenomeres; 4-11 serrate, tubular-shaped. Female antennae shorter than male antennae (Fig. 2); frontoclypeal carena over antenna distinctive, slightly curved, diffuse at middle; frontoclypeal region advanced forward; labrum small, 1.6 times as long as wide; mandibles unidentate (Fig. 4A).

Prothorax elongate, about 1.19-1.30 times as long as greatest width; sides sinuate narrower anteriorly, carinate and emarginate; strongly convex medially; posterior angles broad, produced posterolateraly, apices upwards; base of pronotum without incisions; hypomera simple, basally non excavate; prosternum strongly combed; notosternal suture marginate, sinuated at procoxae, open at anterior end; prosternal process slightly narrower near base, then gradually expanded posteriorly, following procoxae in lateral view, extending well behind procoxae; hypomeron basally impressed to accomodate leg (femur), enlarged, covering epipleura; procoxae subglobular.

Scutellar shield convex, elongate, parallel-sided, anterior border diffuse, posteriorly with a small notch; elytra striate, about 2.34-3.16 times as long at midline as greatest width and 2.63-2.9 times as long as pronotum; parallel-sided at anterior third, narrowing towards posterior third, converging posteriorly, apices rounded, not meeting at central midline; humeri well developed; disc with 10 defined striae, each stria strongly punctate, deep punctures separated by less than one own diameter; mesoventrite not on same plane as metaventrite; articulating lobes of mesosternite rugose; anterior articulating surfaces of mesosternite almost perpendicular to median body line; mesocoxae projecting, mesocoxal cavities narrowly separated, open laterally to mesepimeron and mesepisternum; mesocoxal distance 0.25 times mesocoxal diameter; mesosternal posterior region sinuated, length 0.25 times mesocoxal diameter; mesosternal cavity sides mostly parallel, except at base (Fig. 5A); metacoxae obliquely oriented, with plates extending towards body side; posterior region of mesosternite with length 0.25 times mesocoxal diameter; metasternum between metacoxae elevated. 
Hind wing about 2.46-3.0 times as long as wide; apical field about 0.17 times as long as total wing length, apical field with one oblique long, narrow plate, reaching border of the wing; radial cell well developed, elongate, length 5.0 times as long as wide; cross-vein $r_{3}$ long, length about 4.16 times length of radial cell, horizontal and arising away from $\mathrm{r}_{4}$; base of RP very long, extending to wing base; R-M loop forming narrowly acute angle; $\mathrm{MP}_{3+4}$ branching in 2 straight long veins (arrow); wedge cell legth about 2.7 times its width (Fig. 7A).

Genitalia: Bursa copulatrix elongate, at base with two globular glands, posterior area of bursa with more than 10 long spinules, anterior area of bursa with small sclerotized spicules (Fig. 8A, globular glands not visible on figure).

Tarsomeres 1-3 narrow at base, distally wider; tarsomeres 1-4 with lamellae (Fig. 10); tarsomere 4 significatly smaller than precedents; pretarsal claws simple; empodium short, not extending between claws.

\section{Male}

Same characters as female unless indicated as follows.

Body about 4.45-4.73 times as long as wide; pronotal sides straight; elytral length about 3.11-3.42 times pronotal length; antennomere 11 reaching posterior angles, antennomere 11 elongate, similar in size to antennomeres $4-8$ (Fig. 2).

Prothorax elongated dorso-ventrally, somewhat flattened, except slightly combed medially, pronotal sides strongly emarginate, about $1.04-1.47$ times as long as greatest width.

Genitalia: aedeagus symmetrical. Median lobe attached to parameres (Fig. 11).

\section{Distribution}

Southern Chile, provinces Arauco, Malleco, Cautín, Valdivia and Coihaique.

Sharon amoenus (Philippi, 1861) comb. nov. Figs $1 \mathrm{AB}, 2$, 4A, 5A, 6A, 7A, 9-11

Asaphes? amoenus Philippi, 1861: 743.

Asaphes elegans Candèze, 1878: clxxxix.

Asaphes amoenus - Philippi 1887: 704. — Candèze 1891: 182. — Calvert 1897: 844-855.

Asaphes elegans - Philippi 1887: 704. — Fleutiaux 1907: 216. — Blackwelder 1944: 293.

Parasaphes amaenus [sic] - Fleutiaux 1907: 216-217.

Hemicrepidius amoenus - Blackwelder 1944: 293.

\section{Material examined}

Holotype

CHILE: ㅇ, 14.47 mm; number 2223. Corral, Valdivia (3952' S 73²6’ W) EMEC113160 [MNNC].

\section{Non type material studied}

CHILE: Sharon amoenus. O: Prov. Valdivia / Sto. Dgo. / Valdivia / 28-10-90 / E. Krahmer. (3948'51" S

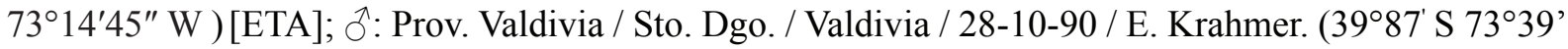
W) [ETA]; ô: Cautín 700 m / Nueva Imperial / 15-XI-81 L Peña/ / Ex Colección Valencia / 005249 [JEB]; ơ: Pichinahuel / Cord Nahuelb. / Arauco Enero 59 / Leg: G. Barría / / Ex Colección Valencia 005231 / /

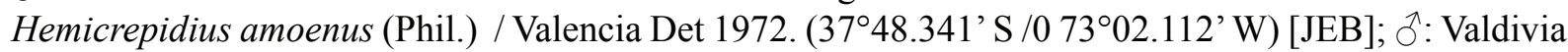




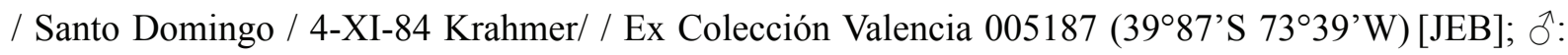
Valdivia Panguipulli / 13.XI.77 Krahmer / Ex Colección Valencia 004976 (39³8’40”S 72¹9'50”W)

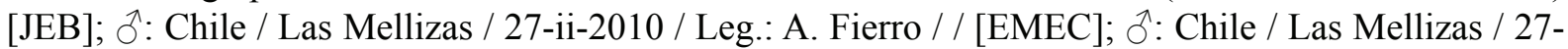
ii-2010 / Leg.: A. Fierro / / [MNNC]; đ̃: Chile Cautín / P. N. Los Paraguas 17-8-1991 / Col. J. Mondaca E. / / Ex Colección Valencia / 003033. (39 $87^{\prime}$ S 73³9' W) (same as National Park Conguillio 38 40’00" S 71³9’00” W) [JEB]; : : (Arauco) 750 m / 1, 19-Enero-54 / Coll. L. E. Peña/ / Ex Colección Valencia 005010 (3746' S 7320' W) [MNNC]; O : Aysén / Coyhaique 7. / Km w 21-I-68 / / Hemicrepidius amoenus (Phil.) / Valencia Det 1976. Ex Col Valencia / JVCC / CHILE 003033 (4346' S 7204' W) [JEB]; : Valdivia / Fdo Caupolican / 22-X-1965 / / HOMOTIPO / Ex Col Valencia / JVCC / CHILE

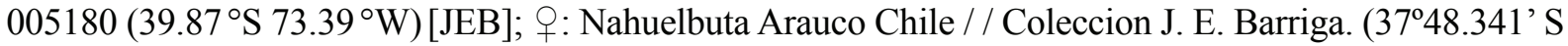
$\left./ 73^{\circ} 02.112^{\prime} \mathrm{W}\right)[\mathrm{JEB}]$.

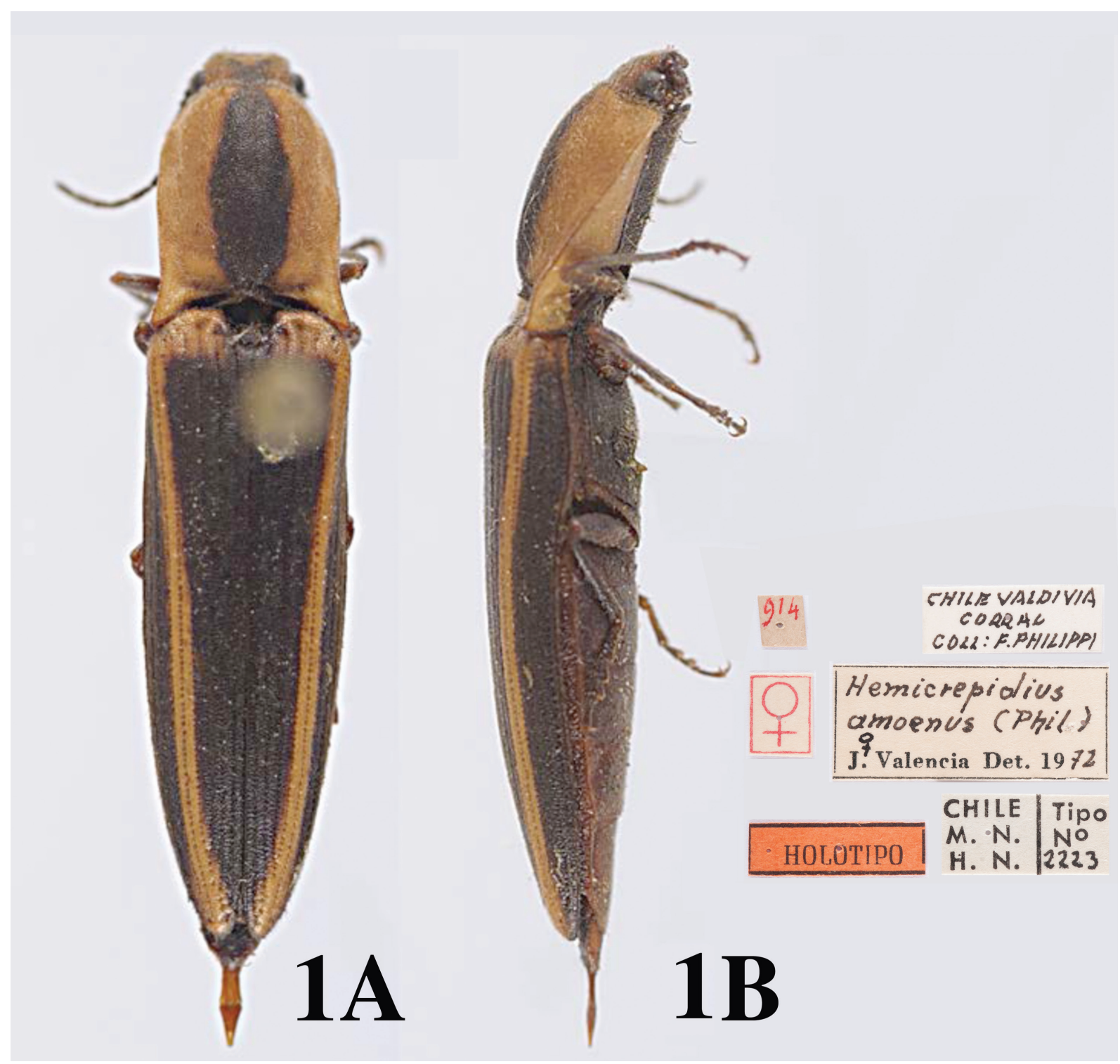

Fig. 1. Holotype of Sharon amoenus (Philippi, 1861) comb. nov., ㅇ, adult (MNNC). A. Dorsal view. B. Lateral view. Body length: $14.47 \mathrm{~mm}$. Photo by Cristian Becker (MNNC). 


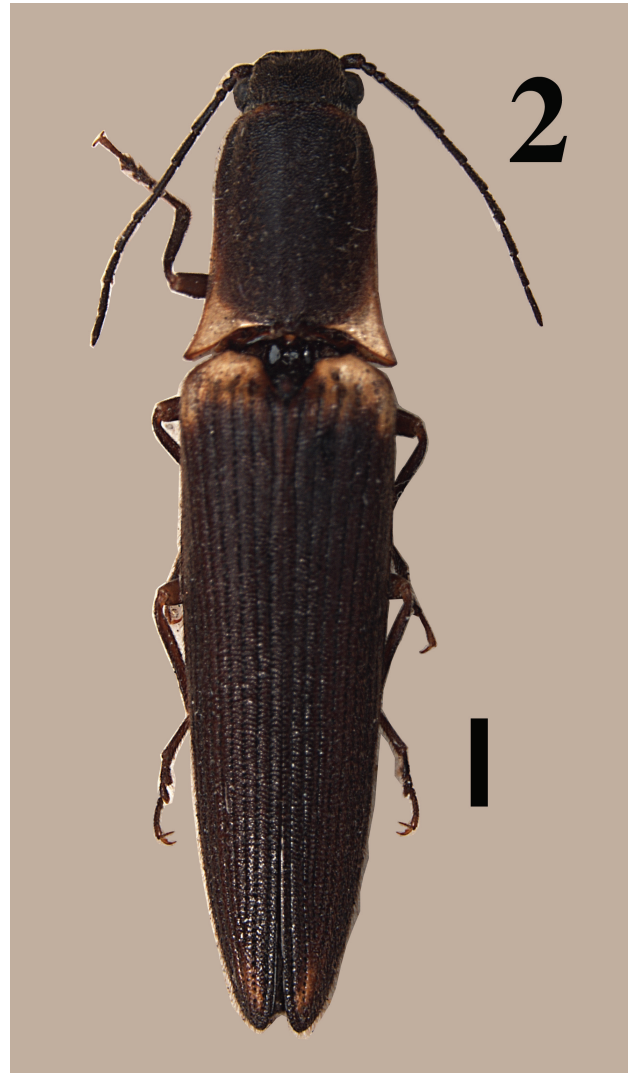

Fig. 2. Adult of Sharon amoenus (Philippi, 1861) comb. nov., $\hat{\jmath}$. Valdivia. Scale bar $=1 \mathrm{~mm}$.

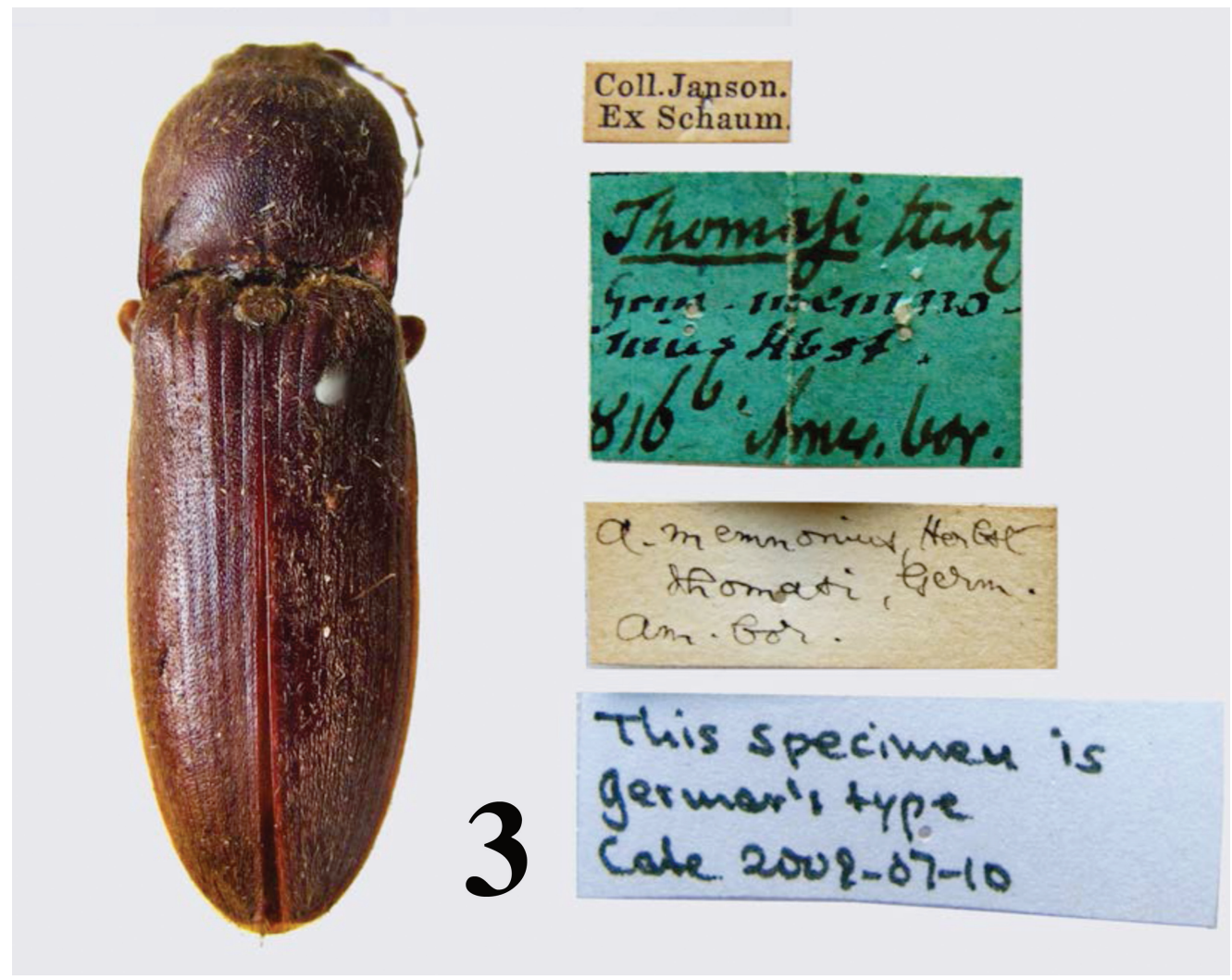

Fig. 3. Adult of Hemicrepidius memnonius Herbst, 1806 [=Asaphes thomasi Germar, 1839, holotype, approximate body length $=18 \mathrm{~mm}]$. Photo by Helena Maratheftis $(\mathrm{BMNH})$. 


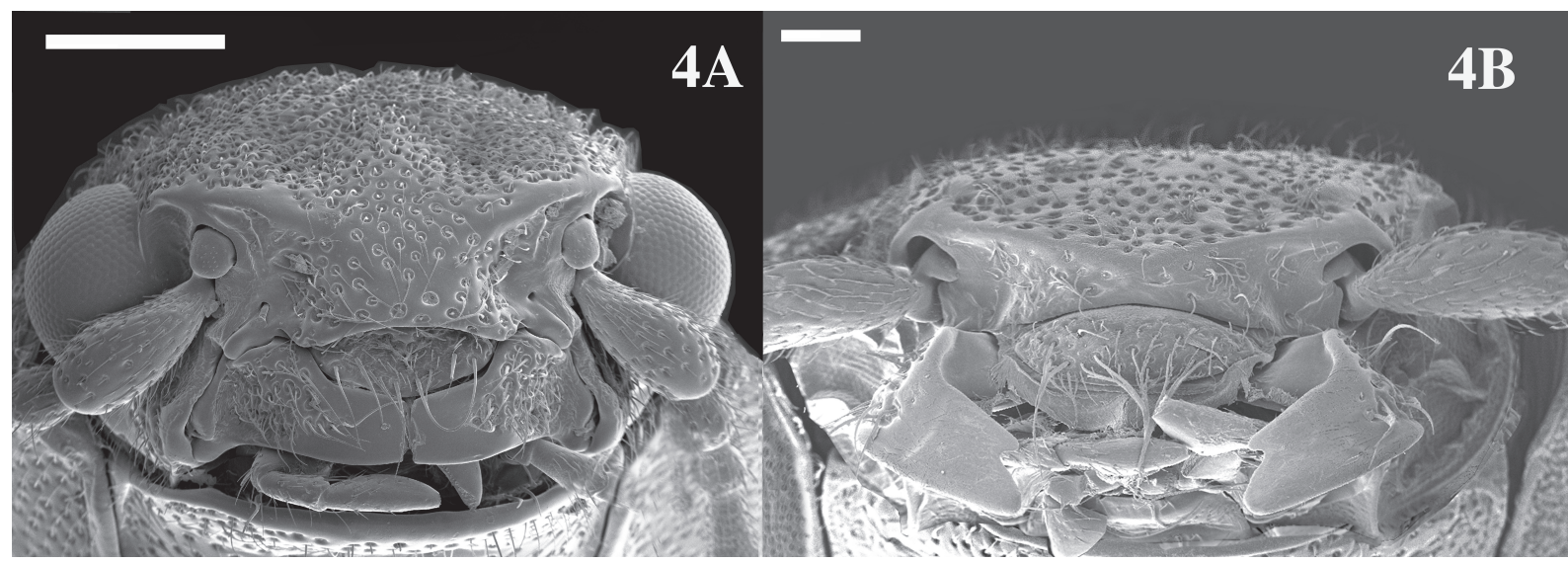

Fig. 4. SEM photographs of head, frontal view. A. Sharon amoenus (Philippi, 1861) comb. nov. B. Hemicrepidius memnonius Herbst, 1806. Scale bars $=0.5 \mathrm{~mm}$.

\section{Comparative material of Hemicrepidius}

O.: Asaphes thomasi Germar, 1839. Holotype studied from photograph material from BMNH in Fig. 3.

J: Kaweah Power House Reservoir \#3 Calif. / Tulare County / Vi.21.1977/ / E. A. Kane Collector/ / Hemicrepidius dilaticollis (Most) M.W. Stone [CDFA]; ठ̊. Kaweah Power House Reservoir \#3 Calif. / Tulare County / VI.14.1973/ / E. A. Kane Collector / / [CDFA], as Hemicrepidius dilaticollis no label present; ㅇ: N. Y./ / Hemicrepidius dilaticollis [ETA]; 우: Pine Ridge / Sharon Co / S. Dak; [EMEC]; §ิ: Quincy, 4mi W plums Co., / Calif. Vi-24-49 / / Hemicrepidius dilaticollis / det M.W. Stone H.U. Hunt / Collector; : : Buffalo N-Y/7-10-69 / E.P.V. Coll E. P. Van Duzen [EMEC]; 9 : Fort Lee /New Jersey / W.S. Cook / Collector H memnonius [ETA]; ${ }^{\top}$ : Putnam Park/18 J 1.39 ct / Almelander/ / H memnonius (Hbst)/Det. Marshall W. stone Collection [CAS].

\section{Comparative material from Australia}

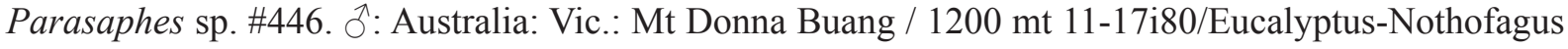
forests A. Newton \& M. Thayer / / ANIC Specimen / [ANIC]; 우: 37.43 S 145.42 E VIC / / Cement

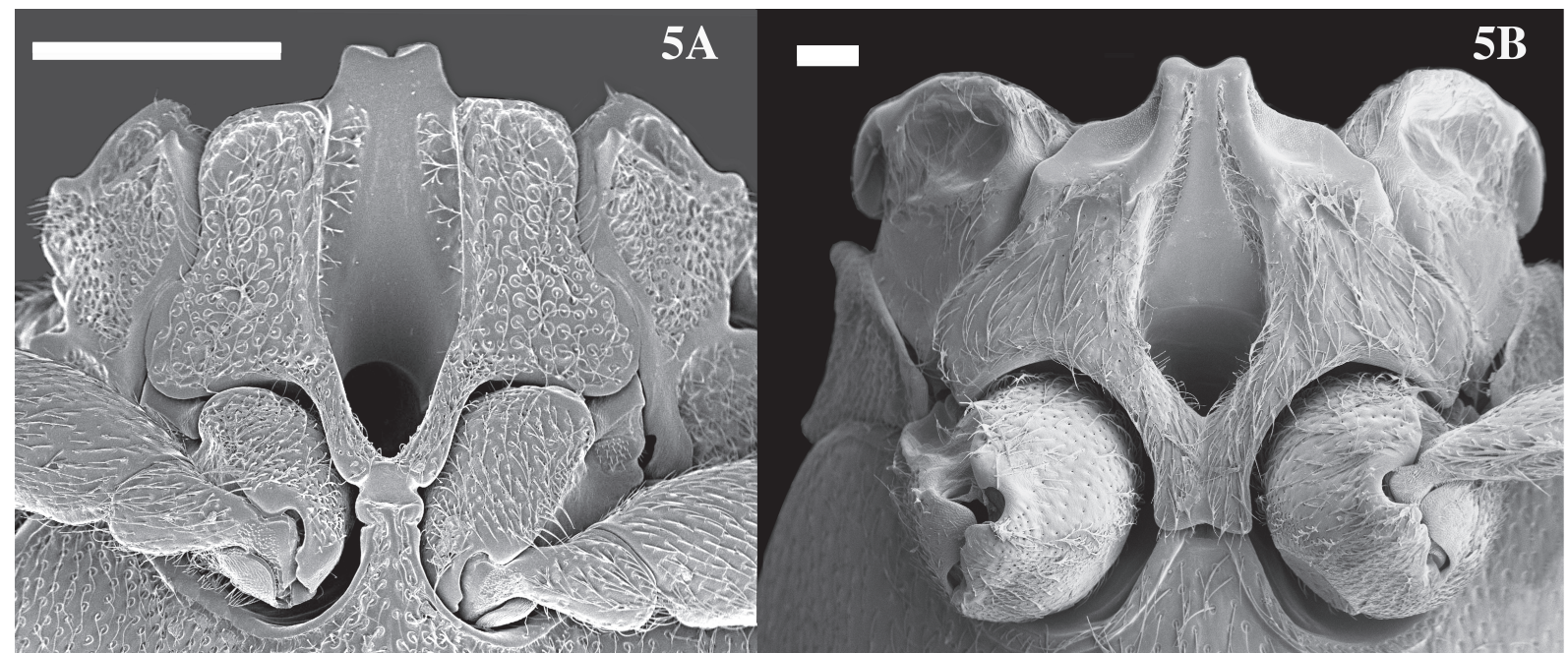

Fig. 5. SEM photographs of mesoventral cavity. A. Sharon amoenus (Philippi, 1861) comb. nov. B. Hemicrepidius memnonius Herbst, 1806. Scale bars $=0.5 \mathrm{~mm}$. 

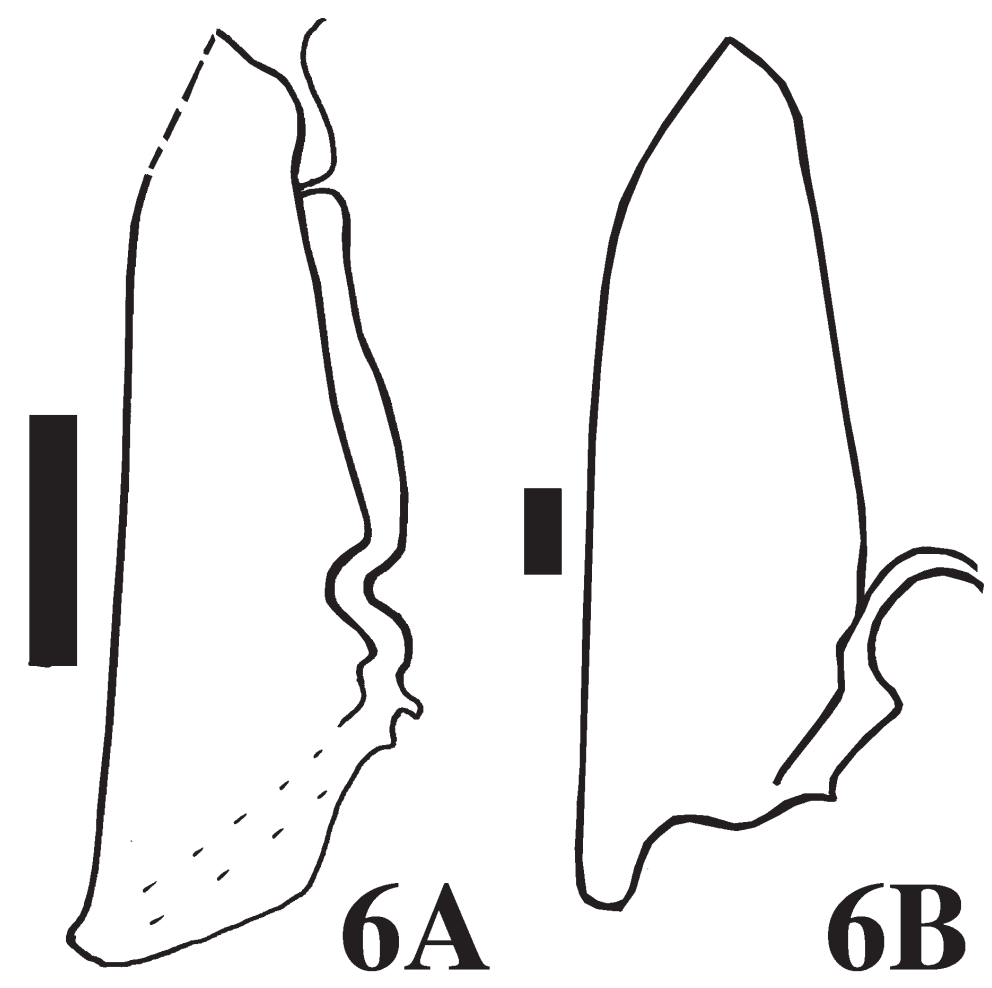

6B

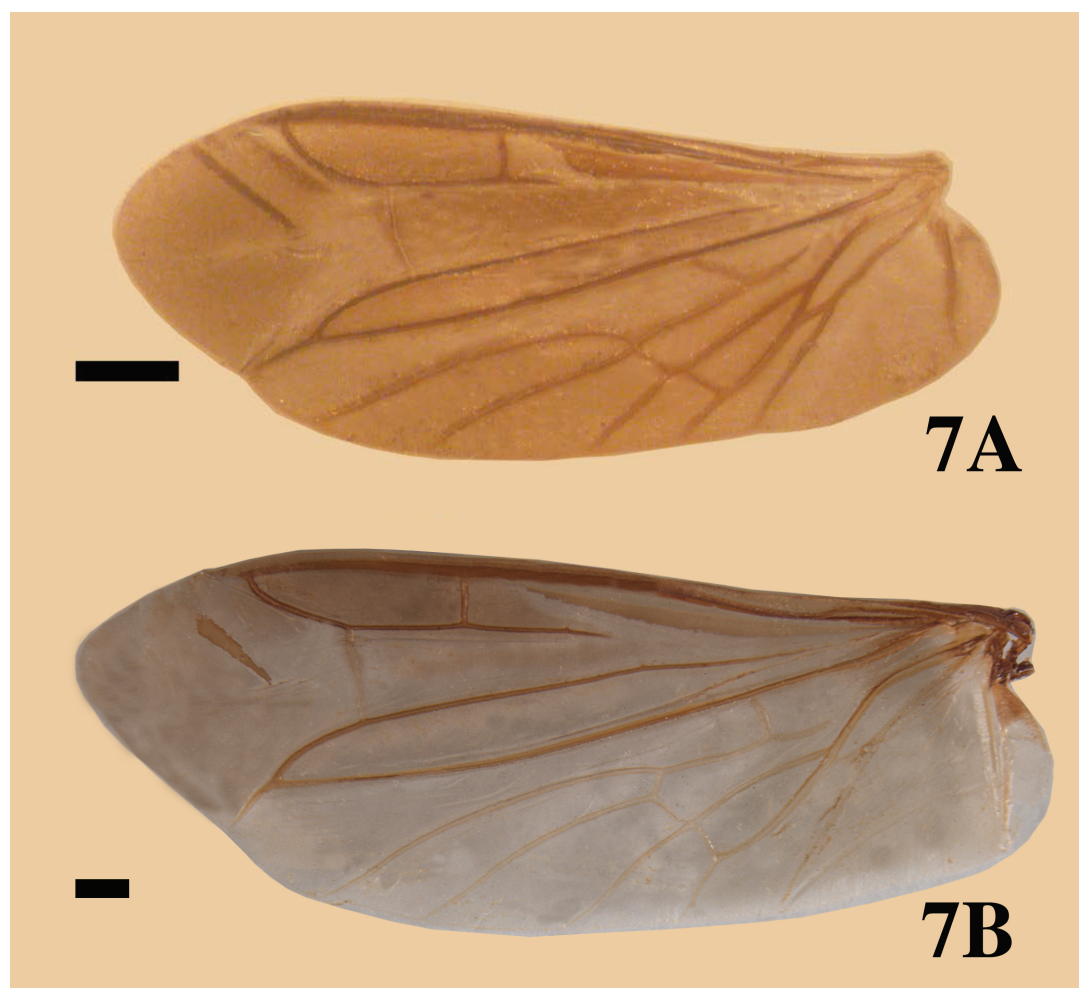

Fig. 7. Wing. A. Sharon amoenus (Philippi, 1861) comb. nov. B. Hemicrepidius memnonius Herbst, 1806. Scale bars $=1 \mathrm{~mm}$. 
ARIAS-BOHART E.T. \& ELGUETA M., Sharon amoenus (Philippi, 1861) gen. nov.

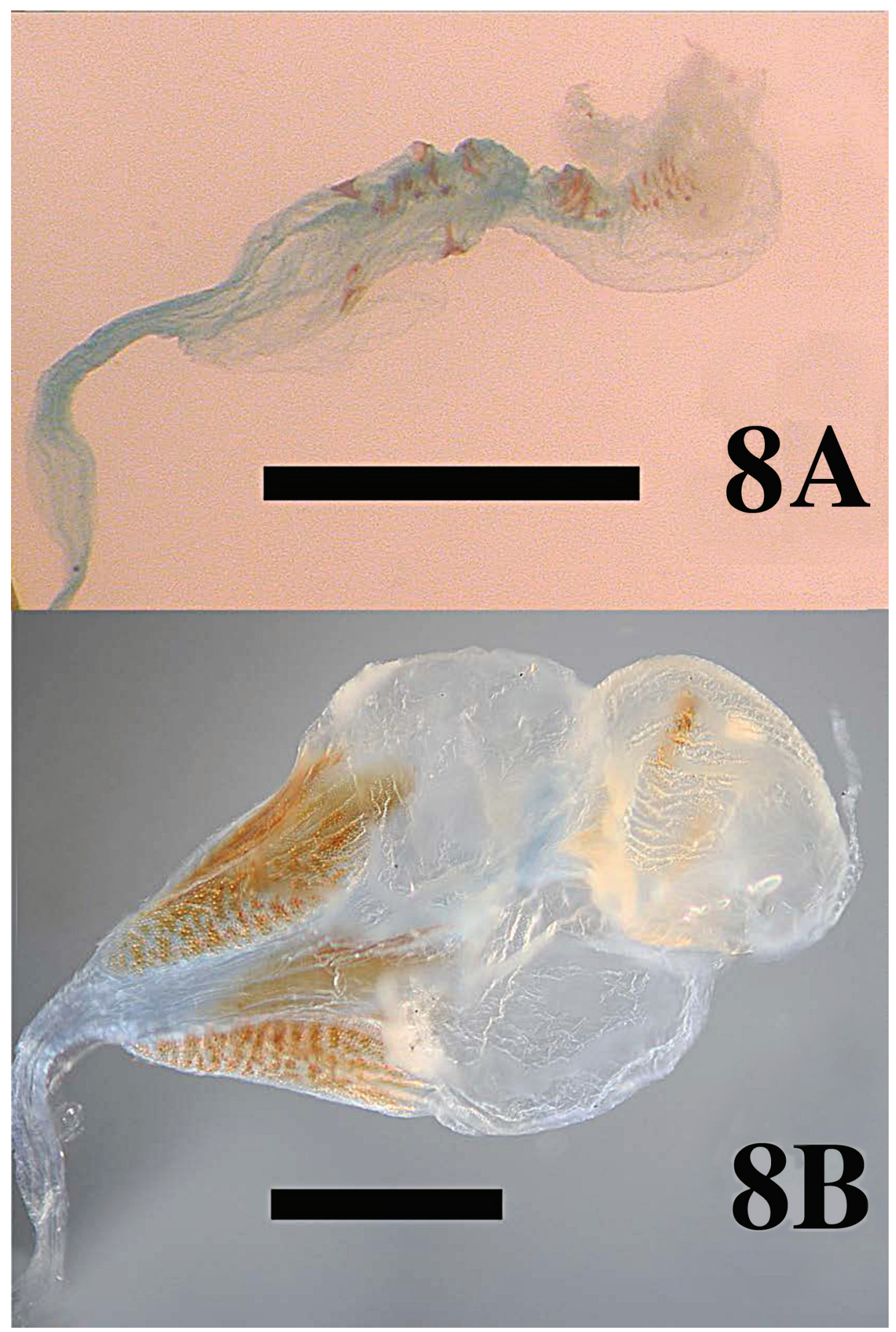

Fig. 8. Female genitalia. A. Sharon amoenus (Philippi, 1861) comb. nov. B. Hemicrepidius memnonius Herbst, 1806. Scale bars $=0.5 \mathrm{~mm}$. 


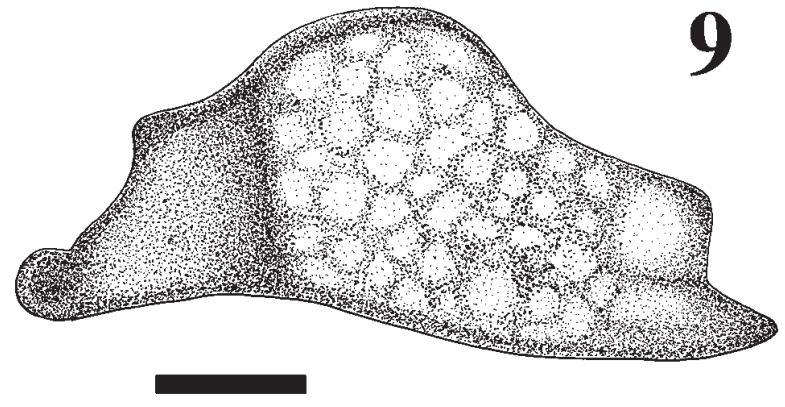

Fig. 9. Mandible of Sharon amoenus (Philippi, 1861) comb. nov. Scale bar $=0.5 \mathrm{~mm}$.

Creek, 670m / N. of Warburton / 81226 Jan.-11 Feb.1997 / A. Newton \& M. Thayer/ / Euc. regnansNoth.cunn/pyrethrin fogging / old fungus logs [ANIC]. [ETA]

Parablax sp. ô: 43.07 S 146.47 E / Edwards rd. TAS. Hartz Mtns. 4 Feb. 1983. I.D. Naumann / J.C. Cardalle Coll. [ANIC] [ETA].

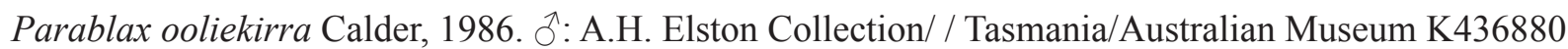
/ / Calder. Det A. Calder 1980 / / Parablax ooliekirra Det A. Calder 1980 / / [NMV].

Parablax moorda Calder, 1986. đ̊: National Park / / NSV / A. Museum 16.x.1921. National Museum K436878 / / Parablax ooliekirra. Det A. Calder 1980 / / Parasaphes elegans? / Candz. [NMV].

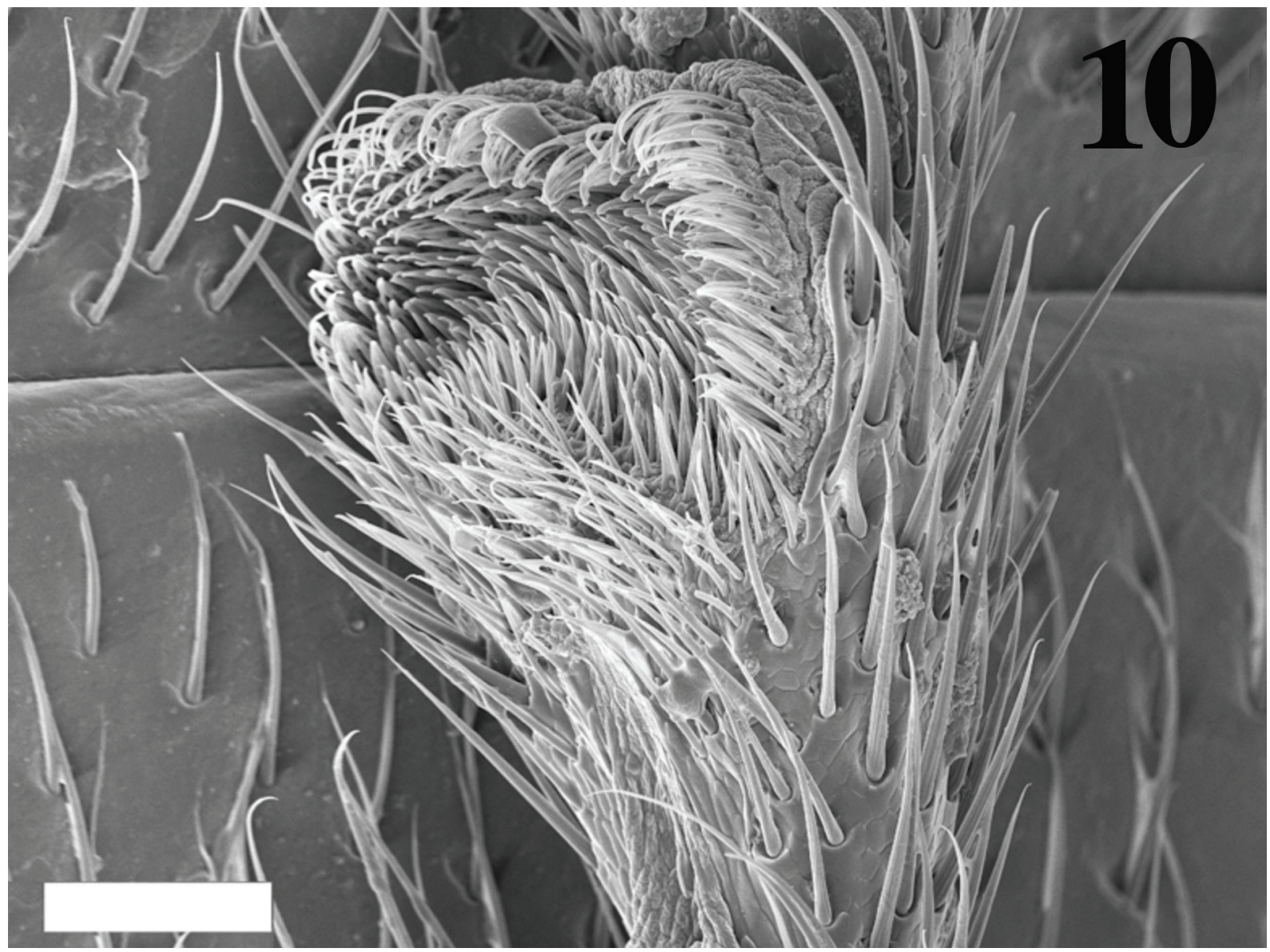

Fig. 10. Tarsomere 3 of Sharon amoenus (Philippi, 1861) comb. nov. Scale bar $=0.5 \mathrm{~mm}$. 
Tasmanelater pelionensis Calder, 1996. đ̊: 880mt 30Nov-8Jan./1991 E Nielsen / E. Edwards malaise\#3 / closed forest/ / Tasmanelater pelionensis / Det A Calder 1996/ / ANIC database No / 25-029504 [ETA]; O : Paratype 42.52S 146.03E TAS / 2km NE by Mt Ossa / 29 Nov 1990 / T. Weir in Swarm on ground 1000/ / Paratype/ / Tasmanelater pelionensis Det A Calder 1996 [BMNH].

Wynarka silvestre Calder, 1986. §̊: Blue Mts N.s. Wales g.E. Bryant 27 Xii 08. Wynarka silvestre Det.

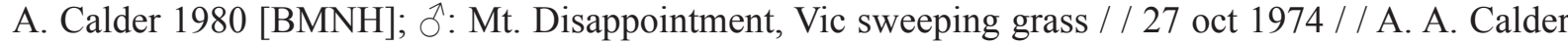
Wynarka silvestre Det. A. Calder 1980 / / Paratype 20305 / / Mus. Vic. / Ento 2015-21 [NMV]; ;: Unreadable / / Female genitalia in a vial / / A.A. Calder 1976 / / Wynarka silvestre Det. A. Calder 1980 / / Paratype 20305 / / Mus. Vic. / Ento 2015-21 [NMV].

\section{Redescription}

Female (holotype)

Total body length $14.47 \mathrm{~mm}$, pronotal width $3.12 \mathrm{~mm}$, elytral width $3.15 \mathrm{~mm}$ (Fig. 1A-B).

Head yellow, with a brown stripe medially; short, semi-erect, gold vestiture; surface finely punctate; antenna not reaching base of posterior angles, same color as head, all antennomeres clothed with erect short hairs; antennomere 2 and antennomere 3 smaller than antennomere 4, antennomere 2 about 0.45 times as long as antennomere 4 , antennomere 3 about 0.39 as long as antennomere 4 ; mandibles brown, with at least 3 long setae (Fig. 9).

Prothorax sides slightly sinuate, narrowing towards head; yellow, with a brown stripe longitudinally, wider near base, with semi-decumbent, curved, gold hairs; punctate, fine punctures separated by more than one own diameter, prosternal spine about 0.25 times as long as diameter of procoxal cavity; hypomeron light yellow, finely punctate.

Scutellum dark brown. Elytra with striae impressed, strongly striate-punctate; most of elytral surface yellow, including humeri; a long lateral brown stripe, narrowing towards elytral apices; abdomen dark brown, finely punctate, with decumbent gold, hairs; legs brown, vestiture black; tarsomeres with lamellae of a lighter color, lamellae 3-4 with strong set of short hairs distally.

Legs brown, vestiture black; tarsomeres $2-3$ with heart-shaped lamellae, medially lighter than the rest of the tarsomere; tarsomere 4 about 0.5 times length tarsomere third (Fig. 10).

\section{Male}

Total body length $11.25-12.76 \mathrm{~mm}$, pronotal width $1.75-2.23 \mathrm{~mm}$, elytral width $2.37-2.76$.

Head dark brown; short, semi-decumbent goldish hairs; posterior angles, humeri and elytral apices yellow; antennae same color as head, not reaching apex of posterior angles, all antennomeres clothed with erect, short hairs; antennomere 2 and antennomere 3 smaller than antennomere 4 , antennomere 2 about 0.41 times as long as antennomere 3 , antennomere 3 about 0.32 times as long as antennomere 4 ; mandibles same color as head.

Prothorax dark brown, semi-decumbent long, gold hairs; paralell-sided for almost all their lengths; somewhat flat, punctate, punctures separated by less than one own diameter; prosternal spine about 1.15 times as long as diameter of procoxal cavity.

Scutellum black. Elytra black, with elytral humeri and apices yellow; with striae impressed, strongly striate-punctate There is variation in the size of the yellow band yellow covering posterior angles, humeri and elytral apices, might be smaller covering only apex of posterior angles, humeral border, small spot 


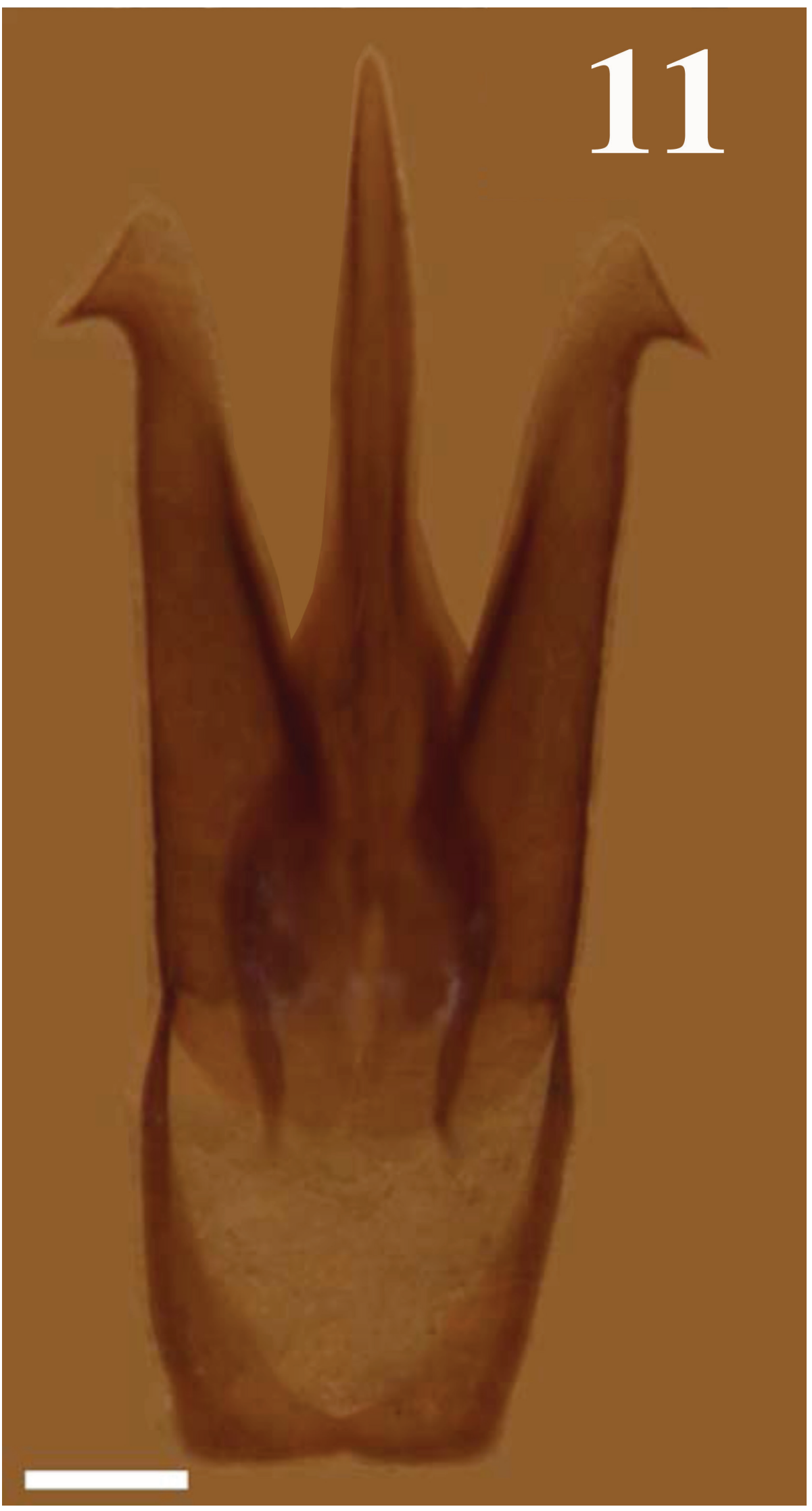

Fig. 11. Male genitalia of Sharon amoenus (Philippi, 1861) comb. nov. Scale bar $=0.5 \mathrm{~mm}$. 
on elytral apices, or larger covering posterior angles and along the pronotal side, extending humeral area as long as scutellar length and almost all elytral apices.

Legs dark brown, vestiture black; tarsomera similar to female.

Aedeagus about $1.25-1.37 \mathrm{~mm}$ long; apex of parameres globose, median lobe much longer than parameres (Fig. 11).

\section{Distribution}

Southern Chile. Sharon amoenus comb. nov. is distributed from the Bío Bío region to the Aysén region (provinces of Arauco, Malleco, Cautín, Valdivia and Coihaique), especially in humid areas of the coastal range (from $37^{\circ} 46^{\prime} \mathrm{S}$ to $39^{\circ} 55^{\prime} \mathrm{S}$ ) and in similar habitats of the Andean Cordillera (from $38^{\circ} 43^{\prime} \mathrm{S}$ to $\left.43^{\circ} 46^{\prime} \mathrm{S}\right)$.

\section{Remarks}

We believe that Philippi based his description of Asaphes amoenus on a unique specimen, which he deposited at the MNNC, Chile.

\section{Discussion}

Sharon amoenus comb. nov. was previously placed in Asaphes and subsequently transferred by Blackwelder (1944) to Hemicrepidius (type species H. memnonius (Herbst, 1806), Fig. 3). However, S. amoenus comb. nov. does not share the generic characters of Hemicrepidius and we have therefore erected Sharon gen. nov. to accomodate this species. Sharon gen. nov. differs from Hemicrepidius by the following characters (contrasting characters for Hemicrepidius in parentheses): frontoclypeal region advanced forward (frontoclypeal region flattened); antennomeres 2-3 about 0.6 times length of antennomere 4 (antennomeres 2-3 similar in length to antennomere 4); prothorax elongate (Figs 1A, 2) (prothorax subquadrate (Fig. 3)); prothorax basally without a notch (prothorax basally with a notch); hypomeron basaly non excavate (Fig. 6A) (hypomeron basaly excavate (Fig. 6B)); prosternal suture marginate (prosternal suture non marginate); sides of mesosternal cavity mostly parallel (Fig. 5A) (sides of mesosternal cavity curved (Fig. 5B)); wing with a long narrow sclerotized plate reaching edge of wing (Fig. 7A) (wing with an elongate irregular-shaped plate, not reaching edge of wing (Fig. 7B)); anterior section of bursa copulatrix elongate with sclerotized spinules (Fig. 8A) (anterior section of bursa copulatrix globose with 2 sets of elongate, comb-shaped sclerotized structures (Fig. 8B)).

Sharon gen. nov. appears to be related to a group of Australian click beetles presently classified within the subfamily Pityobiinae, that includes Parasaphes Candèze, Wynarka Calder, 1996 and Tasmanelater Calder, 1996, suggesting Gondwanan relationships. Other members of Pytiobiinae from Australia that might be related to Sharon gen. nov. are Parablax Schwarz, 1906 and Xuthelater Calder, 1996. Previously, Calder (1986) placed Parablax and Wynarka within the subfamily Crepidomeninae. However, we believe that Parasaphes, Wynarka and Tasmanelater are incorrectly placed within Pityobiinae since they do not share tribal or subfamilial characters with its other included members: Pityobius LeConte, 1854, from North America and Tibionema Solier, 1851, from Chile.

In a future publication we will discuss the relationships between Sharon gen. nov. from Chile and Parasaphes, Wynarka, Tasmanelater and Parablax from Australia, which may be Gondwanan.

\section{Acknowledgments}

To the first author's parents, Guillermo Arias Villegas and Carlota Tobar Vega, for their motivation towards my systematics studies. Patrick Grootaert provided the first author with access to the type 
material and space to conduct research at the Institut Royal des Sciences Naturelles de Belgique and Julien Cillis provided assistance with scanning micrographs. Stephane Boucher and Antoine Mantilleri provided access to the type material and facilities at the Muséum national d'Histoire naturelle. Adam Ślipiński provided material for SEM pertinent to this research. Cate Lenman provided loan material critical for these studies. Max Barclay facilitated type photography and type material (BMNH). Photos of holotypes were taken by Christian Becker (MNNC) and by Helena Maratheftis (BMNH). Sergio Riese, Juan Enrique Barriga Tuñon and Andrés Fierro provided elaterid material. Rosser Garrison and Alfred Newton made valuable suggestions and edited the manuscript. An anonymous reviewer made valuable contributions. The National Science Foundation grant DEB 445413 to E.T. Arias \& K.W. Will and the Evert Schlinger Foundation provided support to E.A.'s research.

\section{References}

Arias-Bohart E. 2013. Tunon, a new genus of Protelaterini (Elateridae: Lissominae) from southern Chile. Pan-Pacific Entomologist 89 (3): 159-167.

Arias-Bohart E. 2014. Carlota, a new genus of Agrypnini (Elateridae: Agrypninae) with a key for Chilean Agrypnini. Zookeys 417: 57-69. http://dx.doi.org/10.3897/zookeys.417.7012

Arnett R.H. Jr., Samuelson G.A. \& Nishida G.M. 1993. The Insect and Spider Collections of the World. Sandhill Crane Press Inc., Gainesville.

Becker E.C. 1958. The phyletic significance of the female internal organs of reproduction in the Elateridae. Proceedings of the Tenth International Congress of Entomology 1: 201-205.

Blackwelder R.E. 1944. Checklist of the coleopterous insects of Mexico, Central America, the West Indies, and South America, Part 2. United States National Museum Bulletin 185: 189-341.

Bouchard P., Bousquet Y., Davies A.E., Alonso-Zarazaga M., Lawrence J.F., Lyal C.H.C., Newton A.A., Reid C., Schmitt M., Ślipiński A. \& Smith A.B.T. 2011. Family group names in Coleoptera (Insecta). ZooKeys 88: 1-972. http://dx.doi.org/10.3897/zookeys.88.807

Calder A.A.1996. Click beetles: Genera of the Australian Elateridae (Coleoptera). Monographs on Invertebrate Taxonomy 2: 1-401.

Calder A.A. 1986. Classification, relationships and distribution of the Crepidomeninae (Coleoptera: Elateridae). Australian Journal of Zoology, Supplementary Series 34 (122): 1-222. http://dx.doi. org/10.1071/AJZS122

Calvert G.B. [or W.B.] 1897. Monografía de los Elatéridos de Chile. Anales de la Universidad de Chile 98: 779-860. [also cited as Bartlett-Calvert, G.]

Candèze E.C.A. 1857. Monographie des Elatéridés. Mémoires de la Société Royale des Sciences de Liège, Tôme premier 12: 1-400. Société Royale des Sciences, Liège.

Candèze E.C.A. 1863. Monographie des Elatéridés. Mémoires de la Société royale des sciences de Liège, Tôme quatrième 17: 1-534. Société Royale des Sciences, Liège.

Candèze E.C.A. 1878. Élatérides nouveaux. Annales de la Société Entomologique de Belgique 21: $188-199$.

Candèze E.C.A. 1881. Élatérides nouveaux. Troisième fascicule. F. Hayez, Brussels.

Candèze E.C.A. 1891. Catalogue méthodique des Élatérides connus en 1890. Imprimerie H. VaillantCarmanne, Liége. http://dx.doi.org/10.5962/bhl.title.47119

Dolin V.G. 1975. Wing venation in click beetles and its significance for the taxonomy of the family. Zoologicheskii Zhurnal 54: 1618-1633. [In Russian]. 
ARIAS-BOHART E.T. \& ELGUETA M., Sharon amoenus (Philippi, 1861) gen. nov.

Fleutiaux E. 1907. Révision des Élateridae du Chili. Revista Chilena de Historia Natural 11: 160-232.

Herbst J. 1806. Natursystem aller bekannten in- und ausländischen Insekten, Käfer. Vol. 10. Pauli, Berlin.

Kirby W. 1837. Fauna boreali-Americana, or, The Zoology of the Northern Parts of British America, Containing Descriptions of the Objects of Natural History Collected on the Late Northern Land Expeditions, under the Command of Captain Sir John Franklin, RN., Vol. 4. Fletcher, Norwich. http:// dx.doi.org/10.5962/bhl.title.39293

Kukalová-Peck J. \& Lawrence J.F. 1993. Evolution of the hind wing in Coleoptera. Canadian Entomologist 125: 181-258.

Kukalová-Peck J. \& Lawrence J.F. 2004. Relationships among coleopteran suborders and major endoneopteran lineages: Evidence from hind wing characters. European Journal of Entomology 101 (1): 95-144. http://dx.doi.org/10.14411/eje.2004.018

Lawrence J.F. \& Arias E.T. 2009. Valdivelater, a new genus of Protelaterini (Elateridae: Lissominae) from the forests of central and southern Chile. Annales Zoologici 59 (3): 319-328. http://dx.doi. org/10.3161/000345409X476422

Lawrence J.F., Beutel R.G., Leschen R.A.B. \& Ślipiński A. 2010a. 1. Changes in classification and list of families and subfamilies. In: Leschen R.A.B., Beutel R.G. \& Lawrence J.F. (eds) Handbuch der Zoologie/Handbook of Zoology. Vol. IV Arthropoda: Insecta Part 38. Coleoptera, Beetles. Vol. 2. Morphology and Systematics (Elateroidea, Bostrichiformia, Cucujiformia partim): 1-7. W. De Gruyter, Berlin.

Lawrence J.F., Beutel R.G., Leschen R.A.B. \& Ślipiński A. 2010b. 2. Glossary of morphological terms. In: Leschen R.A.B., Beutel R.G. \& Lawrence J.F. (eds) Handbuch der Zoologie/Handbook of Zoology. Vol. IV Arthropoda: Insecta Part 38. Coleoptera, Beetles. Vol. 2. Morphology and Systematics (Elateroidea, Bostrichiformia, Cucujiformia partim): 9-20. W. De Gruyter, Berlin.

Philippi F. 1861. VI. Observaciones sobre los lamelicornios de Chile, descritos en la obra del Señor Gay, con descripción de algunas especies nuevas. Anales de la Universidad de Chile 18: 735-744.

Philippi F. 1887. Catálogo de los coleópteros de Chile. Anales de la Universidad de Chile 71: 619-806.

Platia G. 1994. Fauna d'Italia. Coleoptera Elateridae. Edizioni Calderini, Bologna.

Manuscript received: 9 April 2015

Manuscript accepted: 28 July 2015

Published on: 5 October 2015

Topic editor: Koen Martens

Desk editor: Kristiaan Hoedemakers

Printed versions of all papers are also deposited in the libraries of the institutes that are members of the EJT consortium: Muséum National d'Histoire Naturelle, Paris, France; Botanic Garden Meise, Belgium; Royal Museum for Central Africa, Tervuren, Belgium; Natural History Museum, London, United Kingdom; Royal Belgian Institute of Natural Sciences, Brussels, Belgium; Natural History Museum of Denmark, Copenhagen, Denmark. 